\title{
ІНШОМОВНА ПРОФЕСІЙНА ПІДГОТОВКА МАЙБУТНІХ ГЕОГРАФІВ
}

of Ukrainian culture as a whole by I. Krypyakevych. Kyiv: Lybid, pp. 621-648. [in Ukrainian].

2. Ivanytskyi, A. (2004). Ukrainskyi muzychnyi folklor: pidruchnyk dlia vyshchykh uchbovykh zakladiv [Ukrainian musical folklore: a textbook for higher educational institutions]. Vinnytsia: Nova knyha, 320 p. [in Ukrainian].

3. Klyn, V. (1980). Ukrainska radianska fortepianna muzyka [Ukrainian Soviet Piano Music]. Kyiv: Naukova dumka, 316 p. [in Ukrainian].

4. Lastovetska-Solanska, Z. (2016.) Peredmova [Foreword]. Mykola Lastovetsky. Piano plays for children and youth (vol. 3) Editor-in-chief L. Filonenko, Z. Lastovetskaya-Solanska. Drohobych: Posvit, pp. 3 8. [in Ukrainian].

5. Olkhovskyi, A. (2013). Narys istorii ukrainskoi muzyky [The essay of history of Ukrainian music]. Editor, prolusion, comments of $l$. Kornij. Kyiv: Muzychna Ukraina, 512 p. [in Ukrainian].

6. Frait, O. (2013). Fortepianni albomy ta tsykly ukrainskykh kompozytoriv dlia ditei: istoriia $i$ suchasnist [Piano albums and cycles of Ukrainian composers for children: history and modern times]. Drohobych: DSPU named after Ivan Franko Publ., 100 p. [in Ukrainian].

Стаття надійшла до редакції 26.03.2018

УДК 371.134:504

DOI:

Ольга Винник, доиент кафедри іноземних мов для природничих факультетів Наталія Рубель, доцент кафедри іноземних мов для природничих факультетів Львівського національного університету імені Івана Франка

\section{ІНШОМОВНА ПРОФЕСІЙНА ПІДГОТОВКА МАЙБУТНІХ ГЕОГРАФІВ}

У статті розглядаються особливості іншомовної професійної підготовки майбутніх географів. Визначені місие та значення іншомовної професійної підготовки як складової професійної підготовки майбутніх географів. Охарактеризовані напрями та підходи у процесі іншомовної професійної підготовки майбутніх географів. Особливий акиент зроблений на компетентнісному підході у процесі такої підготовки. Визначені иляхи реалізації иьього підходу у процесі такої підготовки. Науково обтрунтовано, визначено і охарактеризовано структуру іншомовної професійно-комунікативної компетенції майбутніх географів. Окреслені шляхи формування такої компетенції у прочесі іншомовної професійної підготовки майбутніх географів.

Ключові слова: професійна підготовка географів; іншомовна професійна підготовка, компетентнісний підхід; іншомовна професійно-комунікативна компетенція.

Puc. 1. Jim. 12.

Olha Vynnyk, Associate Professor of the Foreign Languages for Sciences Faculties Department Nataliia Rubel, Associate Professor of the Foreign Languages for Sciences Faculties Department Lviv Ivan Franko National University

\section{PROFESSIONAL FOREIGN LANGUAGE TRAINING OF THE FUTURE GEOGRAPHERS}

The problem of the professional foreign language training of the future geographers' in the process of the professional future geographers' training is considered. The role and the place of the professional foreign language training in the process of the professional future geographers' training have been defined. This article deals with the competence approach to the professional future geographers' foreign language training. The ways of the realization this approach in the process of the professional future geographers' foreign language training have been analysed.

The definition of the concepts "competence", "communicative competence", "foreign language communicative competence", "professional foreign language communicative competence" have been defined. The professional foreign language communicative competence as a main competence in the process of the professional future geographers' training has been defined. The structure of the professional foreign language communicative competence (PFLCC) of the students majoring in geography has been formed and characterised in the article. A foreign language communicative competence in complex with general professional competence and special professional competence form the key components of PFLCC. The social, personal, general scientific, instrumental and professional competences belong to general groups of competences, forming PFLCC. Creativeness, ability to think in a system way, ability to study, understanding and knowledge of ethical norms of communicative behavior form social and personal competences. Knowledge of fundamental subjects reflect the level of general scientific competence formation. The ability to communicate, perceive and render information in a foreign language as well as in the mother tongue, research skills and computer literacy are the main components of instrumental competences. The necessity of the high level formation of the professional foreign language communicative competence for the future geographers' successful work has been proved. The ways of 
increasing the effectiveness of the professional foreign language communicative competence formation in the process of the professional future geographers' foreign language training has been justified.

Keywords: the professional future geographers' training; the professional foreign language training; competence approach; foreign language professional communicative competence.

П остановка проблеми. Інтеграція України у європейський та світовий простори, значне зростання кількості програм обміну студентами та викладачами зумовлюють постання нових вимог до вітчизняних фахівців різних напрямів підготовки. Головне завдання вищої освіти України - підготовка фахівців нового типу, які реалізовуватимуть цю інтеграцію та гідно конкуруватимуть на міжнародному ринку праці. Значні зміни у цьому напрямку відбуваються зараз у системі вітчизняної вищої освіти, особливо у вивченні базових навчальних дисциплін (у т.ч. іноземних мов). Професійна підготовка фахівців досліджується багатьма вітчизняними та закордонними науковцями. Особливої уваги, на нашу думку, заслуговують дослідження професійної підготовки фахівців нефілологічних спеціальностей, зокрема, фахівців природничих спеціальностей, адже природничі галузі розвиваються надзвичайно активно і потребують фахівців високого професійного рівня.

Виділення невирішених раніше частин загальної проблеми. Особливо гостро в умовах скорочення аудиторних годин для іншомовної професійної підготовки стоїть питання оптимізації цієї підготовки протягом навчання у виші. Адже, досягнення високого рівня цієї підготовки студентами природничих спеціальностей за відсутності викладача, тобто у значній мірі, самостійно, виявляється досить важко, а часом навіть неможливо. Перш за все, це зумовлено відсутністю необхідності складання іспиту $3 \mathrm{HO}_{3}$ іноземної мови при вступі на природничі спеціальності вишів, що призводить до досить низького початкового рівня іншомовної підготовки у студентів на стартовому етапі цієї підготовки. Такі проблеми у процесі іншомовної професійної підготовки майбутніх фахівців природничих спеціальностей, загалом, а майбугніх географів, зокрема, зумовлюють необхідність пошукунових напрямів та підходів для оптимізації цієї підготовки.

Проблема підвищення ефективності іншомовної професійної підготовки майбутніх географів слугує темою багатьох наукових досліджень. Проте питання теоретичного аналізу шляхів реалізації компетентнісного підходу до іншомовної професійної підготовки майбутніх географів висвітлено в наукових дослідженнях не в повному обсязі.
Аналіз основних досліджень і публікацій. Вивчення питання оптимізації процесу професійної підготовки майбутніх фахівців природничих спеціальностей слугувало предметом досліджень значної кількості вітчизняних та закордонних науковців. Теоретичну та методологічну основи дослідження складають положення, засади та висновки фундаментальних теорій i концепцій: міжособистісного спілкування (В. Авраменко, А. Загнітко, В. Куніцина, І. Мегалова, С. Сирьоскіна, О. Степанов, Л. Філіпс та ін.); особистісного та професійного розвитку студентів негуманітарного профілю (М. Архангельська, Г. Білецька, О. Вознюк, Ю. Гапон, Г. Головченко, Р. Гришкова, О. Куліш, Н. Логугіна, Н. Микитенко, І. Молоцька, О. Павленко, Є. Павлютенков, Н. Рідей, С. Рудишин, Г. Скуратівська, С. Старовойт, Н. Сура, Ю. Федоренко, I. Шапошникова, Н. Шеверун та ін.). Проблемами вивчення мовленнєвої діяльності займались: Т. Алєксєєва, М. Галицька, Л. Гапоненко, Т. Глазунова, Ю. Друзь, А. Загнітко, Т. Казарицька, О. Куліш, В. Куніцина, С. Мілорадов, Л. Морська, Н. Сура та ін. Питанням вивчення компетентнісного підходу до процесу підготовки майбутніх фахівців займались науковці: I. Бех, А. Євсєєв, І. Зімняя, В. Луговий, Г. Терещук, Л. Філіппова, А. Хуторськой та ін.

Метою статті $\epsilon$ теоретичний аналіз шляхів реалізації компетентнісного підходу до іншомовної професійної підготовки майбутніх географів.

Виклад основного матеріалу. Іншомовна підготовка відіграє велике значення у майбутній професійній діяльності географів. Адже, особливістю цієї діяльності $є$ те, що географічні дослідження не обмежені кордонами однієї держави. Тому для успішності здійснення професійної комунікації майбутньому географу необхідний високий рівень володіння рідною та іноземною мовами. Здатність майбутніх географів здійснювати іншомовне професійне спілкування стала обов'язковим компонентом їхньої повноцінної професійної діяльності з одного боку, а необхідним результатом їхньої іншомовної професійної підготовки, з іншого.

У Галузевому стандарті вищої освіти України визначено головні завдання професійної підготовки майбутніх географів в умовах входження іiі до Європейського та міжнародного простору. Одне з першочергових - формування готовності до здійснення ефективної 
комунікативної взаємодії в умовах іншомовного професійного середовища, тобто до професійного спілкування. Отже, головним завданням іншомовної професійної підготовки майбутніх географів на сучасному етапі стало формування їхньої готовності до професійного спілкування в іншомовному середовищі.

Процес іншомовної професійної підготовки майбутніх географів повинен проходити певні етапи. У процесі такої підготовки спочатку у майбутніх географів повинен бути сформований належний рівень іншомовної професійної компетенції, на подальших етапах навчання відповідний рівень іншомовної професійної компетентності, і на основі сформованої іншомовної професійної компетентності комунікативно вмотивована готовність до іншомовного професійного спілкування. Саме рівень готовності до іншомовного професійного спілкування визначатиме рівень іншомовної професійної підготовки майбутнього географа.

Такий підхід до процесу іншомовної професійної підготовки називають компетентнісним. Сучасні дослідники визначають компетентнісний підхід як пріоритетну спрямованість на цілівектори освіти (навчання, учіння, самовизначення, самоактуалізацію, соціалізацію і розвиток індивідуальності). Інструментальними засобами досягнення цих цілей виступають принципово нові освітні конструкти: компетентності, компетенції і метапрофесійні якості $[1 ; 3 ; 4]$.

Поняття “компетенція" вперше було застосоване у 60-х роках в США в контексті діяльнісного навчання і передбачало підготовку фахівців, здатних конкурувати на ринку праці [10, 7]. Поняття “компетенція" і “компетентність" слугують темами багатьох наукових досліджень. Проте однозначного визначення цих понять немає. Значна кількість науковців тлумачать компетенцію як готовність фахівця застосовувати отримані знання на практиці, інші - як здатність вирішувати проблеми [5]. Так, А. Хуторський визначає компетенцію як сукупність взаємопов'язаних якостей особистості (знань, вмінь, навичок, способів діяльності), що ставляться стосовно певного кола предметів і процесів, необхідних для якісної продуктивної діяльності по відношенню до них [11]. М. Галицька вважає, що компетенція означає “єдність знань, навичок і відносин у процесі професійної діяльності, які зумовлені вимогами посади, конкретною ситуацією і цілями організації, сукупність професійно значущих якостей та прояв творчості у процесі професійної діяльності, коло тих питань, які повинна і реально може розв’ язувати людина, що виконує професійну чи соціальну роль”, а поняття “компетентність” науковець визначає як таке, що "характеризує i визначає рівень професіоналізму фахівця, котрий володіє знаннями, уміннями та навичками, що дозволяють йому демонструвати професійно грамотну дію мислення, оцінку, думку у конкретній професійній діяльності” $[2,8]$. Компетенцію як здатність, необхіднудля реалізації мовної діяльності, ввів у широкий науковий обіг Н. Хомський $[12,48]$.

Значна кількість визначень понять “компетенція” і “компетентність”, сформульованих різними дослідниками дозволяють нам визначити поняття “компетенціі”, яке найбільш точно відповідає предмету нашого дослідження, а саме поняття компетенції як сукупності “взаємопов'язаних якостей особистості, що висуваються щодо певного кола предметів і процесів, і $\epsilon$ необхідними для якісноӥ продуктивної діяльності відносно цих предметів і процесів, і впливають на професійну діяльність, роль чи відповідальність"; поняття компетентності як “володіння людиною відповідною компетенцією, а також їі досвід, особисте емоційно-ціннісне ставлення до предмета діяльності, до складових компетентності" [7, 33]. Ми також підтримуємо думку А. Хуторського, що комунікативна компетенція є однією 3 ключових компетенцій, адже успішність процесу обміну інформацією забезпечується саме здатністю правильно здійснювати комунікацію, пошук, накопичення й розширення обсягу знань у процесі спілкування [11]. Комунікативна компетенція - це знання, уміння та навички, необхідні для розуміння чужих та породження власних програм мовленнєвої поведінки, адекватних цілям, сферам, ситуаціям спілкування $[8,7]$. Іншомовна комунікативна компетенція $є$ важливим компонентом комунікативної культури майбутнього географа 3 одного боку та невід'ємною складовою його підготовки у ВНЗ, 3 іншого.

Соціокультурна компетенція майбутніх географів формується шляхом моделювання у процесі проведення навчальних занять ситуацій міжкультурного спілкування. Реалізація міжкультурного спілкування передбачає адекватні комунікативні дії, взаєморозуміння учасників акту комунікації. Забезпечення успішності такого взаєморозуміння можливе за умови володіння сукупністю відомостей соціокультурного й міжкультурного характеру, а отже - відповідними особливостями невербальної та вербальної поведінки майбутнього географа. 


\section{ІНШОМОВНА ПРОФЕСІЙНА ПІДГОТОВКА МАЙБУТНІХ ГЕОГРАФІВ}

Іншомовна комунікативна компетенція майбутнього географа формується на основі комунікативної, соціокультурної, міжкультурної компетенцій. Ї̈̈ трактуємо як здатність людини виступати в якості суб'єкта спілкування в іншомовному середовищі. Комунікативна компетенція $\epsilon$ інваріантним компонентом іншомовної професійної компетенції. Визначаємо іншомовну професійну компетенцію як здатність застосовувати: 1) знання про лексико-граматичні особливості іноземної мови, різні типи іншомовних дискурсів; 2) вміння й навички сприймати, інтерпретувати, забезпечувати когерентність висловлювань у значущих комунікативних моделях, створювати дискурс у типових ситуаціях професійного спілкування $[5,40]$.

Розвиток і постійне розширення міжнародних контактів визначають іноземну мову як найважливіший засіб професійної комунікації майбутніх географів, що посилює мотивацію у вивченні мов. Сучасний географ повинен також володіти готовністю та здібністю до оволодіння предметними, науковими знаннями у професійному спілкуванні, тобто володіти належним рівнем професійно-комунікативної компетенції. Професійно-комунікативну компетенцію визначаємо як інтегрований компонент комунікативного менеджменту, комунікативної і професійної компетенцій, який передбачає володіння мовою і професійним мовленням на варіативно-адаптивному рівні, а також на рівні вільного ділового спілкування [6, 19]. Ми підтримуємо думку науковця Н. Сури, що професійно-комунікативна компетенція визначається як готовність та здібність до оволодіння предметними та науковими знаннями у професійному спілкуванні. Іншомовну професійно-комунікативну компетенцію майбутнього географа трактуємо (з посиланням на Н. Суру), як володіння ним необхідною сукупністю знань, умінь і навичок, що визначають ступінь сформованості його професійної діяльності, стилю професійного спілкування та його особистості як носія визначених цінностей, ідеалів і професійної свідомості $[9,8]$.

На основі аналізу джерел 3 проблеми дослідження, вимог стандарту вищої освіти та отриманих результатів можемо схематично представити структуру іншомовної професійнокомунікативної компетенції (далі - ІПКК) майбутніх географів (рис. 1).

Іншомовна комунікативна компетенція у комплексі з загально професійними і спеціально професійними компетенціями складають ключові компоненти ІПКК майбутнього географа. До загальних груп компетенцій-складових ІПКК належать соціально-особистісні, загальнонаукові, інструментальні та професійні компетенції. Креативність, здатність до системного мислення, здатність навчатися, розуміння і знання етичних норм комунікативної поведінки та географічна грамотність формують соціально-особистісні компетенції. Знання загальнопрофесійних дисциплін відображають рівень сформованості загальнонаукових компетенцій.

Здатність до усної і письмової комунікації, сприйняття та передавання інформації рідною та іноземною мовами, а також дослідницькі навички і комп'ютерна грамотність є складовими інструментальних компетенцій.

Наступним етапом іншомовної підготовки майбутніх географів $\epsilon$ формування у них належного рівня іншомовної професійної компетентності. Іншомовна професійна компетентність $\epsilon$ інваріантним компонентом професійної компетентності.

Найбільш відповідним у рамках нашого наукового дослідження вважаємо визначення поняття іншомовної професійної компетентності як комплексу відповідних знань, умінь і навичок; компетенцій, як складових іншомовної професійної компетенції; професійної компетентності та іiі компонентів - предметних і галузевих компетентностей; ключових компетентностей, серед них іншомовної комунікативної компетентності та їі інваріантних складових - лінгвістичної, соціокультурної, прагматичної, міжкультурної, референційної, стратегічної компетентностей. Необхідними компонентами іншомовної професійної компетентності, при цьому, є особистий досвід діяльності, належне емоційно-ціннісне ставлення до предмета діяльності, творчий підхід [7, 39].

Отже, процес іншомовної професійної підготовки майбутнього географа повинен завершитись формуванням у нього особистісної інтегративної якості - іншомовної професійнокомунікативної компетенції (рис. 1), основа якої - здатність до здійснення продуктивної комунікативної взаємодії іноземною мовою 3 іншими учасниками комунікації у сфері своєї професійної діяльності, тому одним з ефективних напрямів професійного та особистісного становлення майбутнього географа вважаємо розвиток його комунікативних можливостей.

Висновки. У процесі іншомовної професійної підготовки майбутніх географів у ВНЗ України досить часто використовується текстуальноперекладна методика навчання, яка, як правило, зводиться до рутинного перекладу професійних 


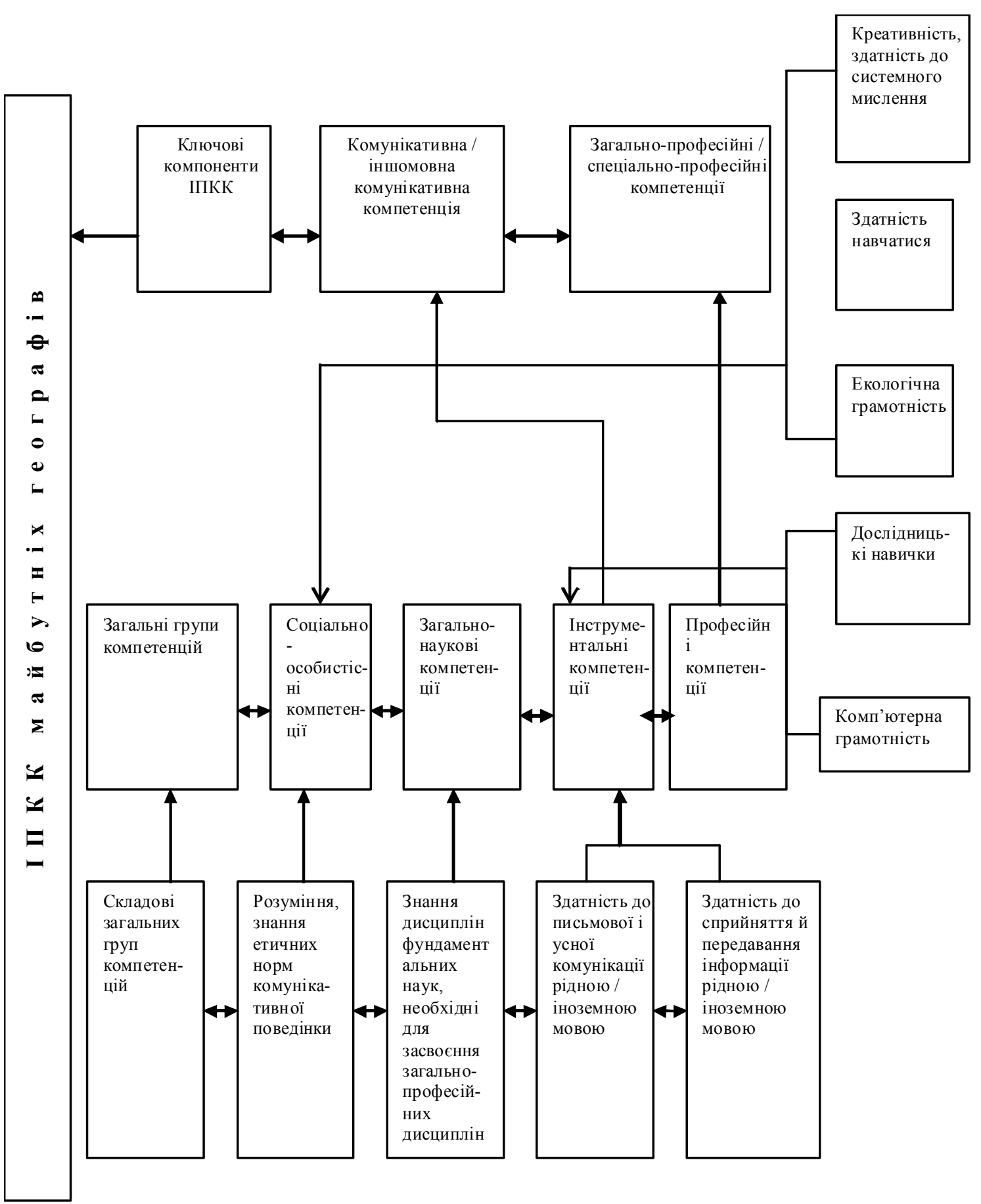

Рис. 1. Структура ІПКК майбутніх географів

текстів, що у майбутньому викликає проблеми у спілкуванні. Сучасний етап розвитку суспільства вимагає від майбутнього географа не тільки розуміння фахових текстів іноземною мовою, а й здатності спілкуватись. Нові вимоги зумовлюють необхідність звертання до нових підходів, комунікативних та інтенсивних методів навчання, переорієнтацію на навчання спілкуванню іноземною мовою, інакше кажучи, результатом іншомовної професійної підготовки майбугнього географа на сучасному етапі повинно бути формування іншомовної професійної компетенції,

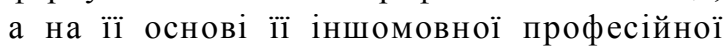
компетентності. Головна мета вивчення іноземної мови $\epsilon$ не лише сама мова, але й мовленнєва діяльність, тобто здатність майбутнього географа якісно спілкуватись іноземною мовою для вирішення професійних завдань. Тому, метою 
такого навчання повинне бути формування комунікативних умінь: говоріння, аудіювання (розуміння на слух), читання і письма, а також вміння використовувати ці навички для вирішення комунікативних завдань професійного характеру. Використання компетентнісного підходу до іншомовної професійної підготовки географів, на нашу думку, забезпечить майбутнього географа комплексом знань, умінь, навичок, які дозволять йому успішно використовувати іноземну мову як у професійній діяльності, так і для самоосвіти і саморозвитку особистості.

Підвищення якості іншомовної професійної підготовки як складової сучасної вищої освіти дозволить фахівцям-географам розширювати міжнародні контакти $з$ фахівцями інших країн, обмінюватись досвідом роботи, брати участь у спільних проектах, науково-дослідницьких програмах.

Перспективи подальших досліджень. Особливості іншомовної професійної підготовки майбутніх географів не вичерпуються аналізом шляхів реалізації компетентнісного підходудо цієї підготовки. Перспективи подальших досліджень цієї проблеми можуть охоплювати аналіз шляхів реалізації інших наукових підходів до іншомовної професійної підготовки майбутніх географів як в Україні, так і за кордоном.

\section{ЛІТЕРАТУРА}

1. Бех І. Д. Теоретико-прикладний сенс компетентнісного підходу в педагогіці / І. Д. Бех / / Педагогіка і психологія: Вісник АПН України. 2009. - № 2. - С. 27 - 33.

2. Галицька М. М. Формування у студентів вищих навчальних закладів сфери туризму готовності до іншомовного спілкування: автореф. дис. на здобуття наук. ступеня канд. пед. наук: спец. 13.00.04 “Теорія та методика професійної освіти” / М. М. Галицька. - К., 2007. - 20 с.

3. Евсеев А. Б. Компетентностный подход к профессионально языковой подготовке менеджеров туризма в вузе: автореф. дис. на соискание ученой степени канд. пед. наук: спец. 13.00.08 “теория и методика профессионального образования" / А. Б. Евсеев. - Москва, 2011. - 26 с.

4. Зеер Э. Ф. Модернизация профессионального образования: компетентностный подход: учеб. пособ. / Э. Ф. Зеер, А. М. Павлова, Э. Э. Сыманюк. - М.: Наука, 2005. - 215 с.

5. Зимняя И. А. Ключевые компетенции - новая парадигма результата образования / И. А. Зимняя // Высшее образование сегодня. - 2003. - №5. C. $35-41$.
6. Луговий В. І. Європейська концепція компетентнісного підходу у вищій школі та проблеми їі реалізації в Україні / В. І. Луговий // Педагогіка і психологія : Вісник АПН України. 2009. - № 2. - C. 14 - 27.

7. Микитенко Н. О. Технологія формування іншомовної професійної компетентності майбутніх фахівців природничого профілю / Н. О. Микитенко. - Тернопіль : ТНПУ ім. В. Гнатюка, 2011. - 411 с.

8. Степко М. Ф. Компетентнісний підхід до організації підготовки фахівців, його розуміння і проблеми використання у вищій школі України / М. Ф. Степко // Педагогіка і психологія: Вісник АПН України. - 2009. № 2. - С. $44-50$.

9. Сура Н. А. Навчання студентів професійноорієнтованого спілкування іноземною мовою: автореф. дис. на здобуття наук. ступеня канд. пед. наук: спец. 13.00.04 “Теорія та методика професійної освіти” / Н. А. Сура. - Луганськ, 2005. -20 c.

10. Федоренко Ю. П. Формування у старшокласників комунікативної компетенції в процесі вивчення іноземної мови: автореф. дис. на здобуття наук. ступеня канд. пед. наук: спец. 13.00.09 "Теорія навчання" / Ю. П. Федоренко. Луцьк, 2005. - 19 с.

11. Хуторской А. В. Ключевые компетенции и образовательные стандарты // Интернет-журнал “Эйдос". - 2002. - 23 апреля. - [Електронний pecypc]. - Режим доступа: 03.12.2004: < http:// www.eidos.ru/journal/2002/0423.htm >. В надзаг: Центр дистанционного образования “Эйдос". Язык рус.

12. Chomsky N. Knowledge of Language. Its Nature, Origin, and Use / N. Chomsky. - Westport: Praeger Publishers, 1986. - xxix + 314 p. (Convergence).

\section{REFERENCES}

1. Bekh, I.D. (2009). Teoretyko-prykladnyy sens kompetentnisnoho pidkhodu $\mathrm{v}$ pedahohitsi [Theoretical and applied sense of competence approach in pedagogy]. Pedagogy and Psychology: Bulletin of the Academy of Pedagogical Sciences of Ukraine. Vol. 2. pp.27-33. [in Ukrainian].

2. Halyts'ka, M. M. (2007). Formuvannya u studentiv vyshchykh navchal'nykh zakladiv sfery turyzmu hotovnosti do inshomovnoho spilkuvannya [The formati, 3 on of students of higher education institutions in the sphere of tourism readiness for foreign language communication]. Extended abstract of candidate's thesis. Kyiv, 20 p. [in Ukrainian].

3. Yevseev, A. B. (2011). Kompetentnostnyy podkhod $\mathrm{k}$ professionalno yazykovoy podgotovke menedzherov turizma v vuze [Competitive approach 
to professional language training of tourism managers in high school]. Extended abstract of candidate's thesis. Moscow, 26 p. [in Russian].

4. Zeyer, A. M., Pavlova, A.M. \& Symanyuk, E.E. (2005). Modernizatsiya professionalnogo obrazovaniya: kompetentnostnyy podkhod: ucheb. posob. [Modernization of professional education: competence approach: Textbook]. Moscow: Science, 215 p. [in Russian].

5. Zimnyaya, I. A. (2003). Klyuchevyye kompetentsii - novaya paradigma rezultata obrazovaniya [A Key competences - a new paradigm of the result of education]. Higher education today. Vol. 5, pp. 35 - 41. [in Russian].

6. Luhovyy, V. I. (2009). Yevropeyska kontseptsiya kompetentnisnoho pidkhodu u vyshchiy shkoli ta problemy yiyi realizatsiyi v Ukrayini [The European Concept of Competence Approach in Higher School and Problems of its Implementation in Ukraine]. Pedagogy and Psychology: Bulletin of the Academy of Pedagogical Sciences of Ukraine. Vol. 2. pp.1427. [in Ukrainian].

7. Mykytenko, N.O. (2011). Tekhnolohiya formuvannya inshomovnoyi profesiynoyi kompetentnosti maybutnikh fakhivtsiv pryrodnychoho profilyu [Technology of formation of foreign professional competence of future specialists of prospective specialists of sciences: monograph]. Ternopil. Ternopil National University of Pedagogy Publ., 411 p. [in Ukrainian].

8. Stepko, M. F. (2009). Kompetentnisnyy pidkhid do orhanizatsiyi pidhotovky fakhivtsiv, yoho rozuminnya i problemy vykorystannya u vyshchiy shkoli Ukrayiny [Competency approach to the organization of training specialists, his understanding and problems of use in higher education in Ukraine]. Pedagogy and Psychology: Bulletin of the Academy of Pedagogical Sciences of Ukraine. Vol. 2. pp.4450. [in Ukrainian].

9. Sura, N. A. (2005). Navchannya studentiv profesiyno-oriyentovanoho spilkuvannya inozemnoyu movoyu [Teaching of students of professionally oriented communication in a foreign language]. Extended abstract of candidate's thesis. 20 p. [in Ukrainian].

10. Fedorenko, Yu. P. (2005). Formuvannya u starshoklasnykiv komunikatyvnoyi kompetentsiyi v protsesi vyvchennya inozemnoyi movy [Formation of senior pupils of communicative competence in the process of studying a foreign language]. Extended abstract of candidate's thesis. Lutsk. 19 p. [in Ukrainian].

11. Khutorskoy, A. V. (2002). Klyuchevyye kompetentsii $i$ obrazovatelnyye standarty [Key Competencies and Educational Standards]. InternetJournal "Eidos". April 23. [Electronic resource]. Access mode: 03.12.2004: <http: // www.eidos.ru/ journal/2002/0423.htm $>$. Center for Distance Education "Eidos"]. [in Russian].

12. Chomsky, N.(1986). Knowledge of Language. Its Nature, Origin, and Use. Westport: Praeger Publishers, $x x i x+314$ p. - (Convergence). [in English].

Стаття надійшла до редакції 19.03.2018

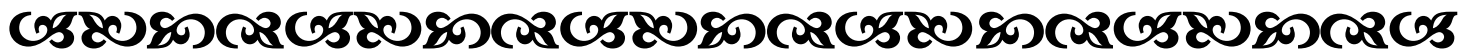

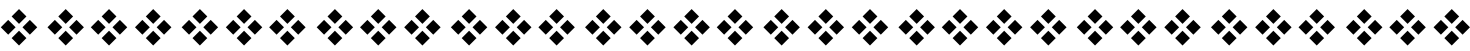

"Dо вивчення наукведе подвійний шлях - авторитет та розум. У відношенні до часу (тобто в історичній традииї) панує авторитет, а у відношенні до суті справи розум. Авторитет буває частқово божественний, частқово людський, але істинний, міиний та найвищий авторитет є той, яқий зветься божественним".

Августин Аврехій

богослов раннвого християнства, церқовний письменник

"Успіх однієї відважної людини завжди спонуқає до завзяття й мужності иіле покоління".

Оноре де Бальзак франиузький романіст і драматург

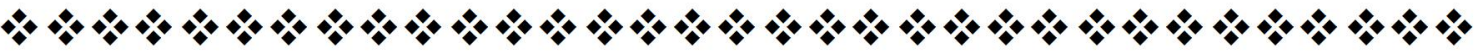

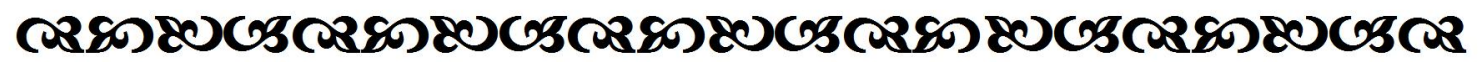

